\title{
Transmedia Digital Inclusion
}

\author{
Otniel Altamirano \\ UABJO; UNESP, Bauru \\ Deputado Joao Sussumo Hirata 600 \\ Sao Paulo, SP, Brazil \\ otniel_digital@hotmail.com
}

\author{
Cristina Portugal \\ RCA, London \\ Dorando Close, Garden House. White \\ City W127TU, London, UK \\ crisportugal@gmail.com
}

\author{
Monica Moura \\ UNESP, Bauru \\ Av Eng Luiz Edmundo Carrijo Coube, \\ no 14-01 Bauru, SP, Brazil \\ monicamoura.design@gmail.com
}

\section{INTRODUCTION}

The discussion that will be undertaken in this article, considers that technological development is one of the factors that encourages paradigm changes in the thoughts and actions of individuals. Considering the aforementioned, and through an exploratory methodology, we present examples from México, Kenya and Brazil, with actions developed by institutions that could consider using the transmedia parameters: Gamification; Custom Experience; Storytelling; Globalization; Multiplatform and Multiformat; and Technical Aspects. These can be incorporated in new projects and potentiate strategies for probably, one of the most significant issues of modern society: digital inclusion. Then, as Martel (2015) says, the digital universe can serve as a tool for empowerment, survival, teaching, economy and urban revitalization in the areas of misery, in the ghettos, favelas, neighbourhoods and areas of extreme poverty. These types of projects are situated in a context that is often difficult to access geographically or with high levels of danger.

\section{TRANSMEDIA LANGUAGE}

New media has been adopted as a tool for the dissemination of data that, when classified under a contextual logic, are transformed into information that is consumed and shared among users and later becomes a collective knowledge. Based on this premise, we will enter into a transmedia language. Gosciola (2014) indicates that the term 'transmedia narrative', first appeared as transmedia composition, a concept created in 1975 by the composer Stuart Saunders Smith, while composing the play Return and Recall, and was basically the composition of harmonious melodies and different rhythms for each instrument. In later years, more researchers and practitioners continued to use the concept, and it became a language.
In the same sequence, Sabbatini (2011) determines that the perspectives of individuals or groups who are traditionally excluded from the process of mass communication, so characteristic of Industrial Age society, may find their voice or turn to construct their identity in digital spaces. We are referring, of course, to a folk-communicational perspective of convergent media. On the other hand, Scatolim, Santos (2016) believes that technological improvement should be able to guarantee products that can be used by anyone, or by as many users as possible. For this, it is not enough to classify and legalize products and services; it is necessary to make access possible.

\subsection{Transmedia language parameters}

Our research aims to consider the following transmedia parameters indicated by the researcher Gosiola (2014), to incorporate in new projects and strategies for digital inclusion:

- Gamification: To get users to participate, to manage content, to search history, to form their own communities, and share it across online and offline social networks. Through a game, that activates all neurological and physiological systems.

- Custom Experience: The change of paradigm to a productive level, including the individualised use of devices and media consumption, recognising the importance of the personal experience. The information comes from users such as: blog, websites, social networks, etc.

- Storytelling: Emotions evoked from relations established within the story, emotional identification with the narrated, the need to tell stories, and know how to do it.

- Globalization: In the digital era of "do it yourself" and low-cost production, which increases the feasibility of creating local projects, which may discuss the value of a 
place, the importance of proximity, the domain and knowledge of the surroundings.

- Multiplatform and Multiformat: The production of narrative worlds that are built through different platforms, each bringing different characteristics to the narration, and hence the multiplicity of formats for the construction of the project.

- Technical Aspects: Though they are not necessarily always characteristics of transmedia, we may consider geolocation, online-offline multiplatform interactive games, Augmented Reality, Mapping under the creation of maps and visualisation of data. These may be significant in the development of transmedia projects.

See below examples from México, Kenya and Brazil about actions developed by institutions with Digital Inclusion initiatives.

\section{INITIATIVES AND PROJECTS FOR DIGITAL INCLUSION}

\subsection{PMC Punto México Conectado, Mexico}

This project has been consolidated in Mexico, which articulates technology and society. Punto México Conectado - Digital Inclusion Center, is described on its official website http://pmc.gob.mx/ as a national network of training and digital education community centers, that consists of 32 points, one in each state of the country, in which anyone can connect with new information technologies, learn to use them, develop their creativity and undertake innovative projects. PMC integrates spaces for the development of skills, through courses, educational activities and practices for all ages, in order to learn about the uses of the Internet, computer, robotics, mechanics and programming. Each point has the following programs: Digital ABC Skills; Technological Innovation; Miscellaneous Digital; and Digital Culture.

\subsection{Projects of Kibera, Kenya}

Martel (2015) explains that Kibera is one of the most populated favelas in the world and it's difficult to locate it. A grey mass that contrasts with the other neighbourhoods of Nairobi in Kenya, in this area there are ghettos of great poverty. The Map Kibera project was developed by a non-profit association, Ushahidi ("witness" in Swahili). A team of volunteers feeds the map. It is available on the Internet (mapkibera.org) and includes passages, dirt roads, drinking water points, clean public toilets, schools, churches and cyber cafes. The information on the platform is constantly updated, it's free and collective, due to the collection of mass data provided by the public, the data is organized with geolocation and after it is confirmed, it is published. Kibera TV, Map Kibera and Blog Voice of Kibera, are some of the totally digital favela medias. The filmmakers conceived a television network available on YouTube. They produce hundreds of short films of two or three minutes to portray Kibera's life in a "positive" way.

\subsection{Favela projects, Brazil}

The same researcher mentioned Martel (2015), described that the Alemão complex is one of the largest favela conglomerates in Rio de Janeiro, which was pacified in 2010. There is a Digital Inclusion Center, under the slogan: "Transforming lives through technology". In the same city is the headquarters of Viva Favela; about ten activists maintain a community blog to tell the life in the favelas, leaving aside the preconceptions of the mainstream printing press. For the first time, articles, information, photos, videos made by the inhabitants of the favelas are offered. On the other hand, there is also the Committee for the Democratization of Information (CDI), which has the purpose to create and educate people to become community managers, entrepreneurs, who create applications, websites and startups. They ensure that by using technologies in a positive way, they can make people change makers and change the world. In summary, this is a creator of trainers.

\section{CONCLUSION}

As we have explored through the projects developed by the three emerging countries presented, they have points of contact in their realities, actions and solutions; some of them have more or less infrastructure and even, they may have the support of their governments. With this, we can clearly observe, that a large part of the activities carried out are directed towards projects that can be described as transmedia, which already execute some of the parameters of this language. In order to enrich them, diversification, expansion and innovation in this type of projects have to be encouraged with the implementation of new tools offered by transmedia, representing a profound transformation in the lives of the inhabitants, beyond digital inclusion, to get a better inclusion to improve their quality of life.

\section{REFERENCES}

Gosciola, V. (2014) Narrativas transmedia entre teorias y prácticas. Narrativa transmidia: conceituação e origens. Edit. Oberta UOC Barcelona.

Martel, F. (2015) Smart. Civilização Brasileira, Brazil. 
Punto México Conectado. Nosotros- Punto México Conectado. http://pmc.gob.mx/ - section-puntos (retrieved 10 March 2018).

Sabbatini, M. (2011) A folkcomunicação na era da convergência midiática digital: da folksonomia às narrativas folkmidiáticas transmídia. Razón y Palabra, 16(77). Instituto Tecnológico y de
Estudios Superiores de Monterrey Estado de México, Mexico.

Scatolim, R., and Santos, J. (2016) Aplicação de sistemas mecânicos em projetos de produtos inclusivos voltados aos portadores de deficiência. Paschoarelli, L.; Fernández, R. Design, Arquitetura e Urbanismo: Transversalidades. Canal 6, Bauru. 